\title{
A comparative study on spatial configuration of human settlements in Riparian Area \\ (Case studies : Old Kampoong and Colonial Settlements in Palembang)
}

\author{
Johannes Adiyanto $^{\mathrm{a}^{*}}$, M. Fajri Romdhoni ${ }^{\mathrm{a}}$, Hendi Warlika SP. ${ }^{\mathrm{a}}$ \\ ${ }^{a}$ Department of Architecture, Engineering Faculty of Sriwijaya University, \\ Jl. Palembang - Prabumulih KM 32 ,Inderalaya (OKI) and 30662, Indonesia \\ *Corresponding author. Tel.: +62 8127141033. \\ E-mail address: johannesadiyanto@ft.unsri.ac.id; johannesadiyanto@yahoo.com
}

\begin{abstract}
Palembang is the city which is divided by Musi River. Palembang is also one of the oldest city in Indonesia. Many old settlements were built in riparian area. This geographic condition of Palembang becomes background of this research. The research questions are: what is the discrepancy between Kampoong and Colonial Settlements in spatial configuration? Does the Musi River have influence in spatial configuration on that case? This research using the space syntax analysis with the following three steps of analysis: convex map analysis, axial map analysis and visibility graph analysis. For case studies, this research names two different settlements: old Kampoong (3-4 Ulu and 10 Ulu) and Colonial settlements (Komperta Plaju and Komperta Bagus Kuning) and we use Kampung Kapitan (7 Ulu) for the comparation. As the result of this research shows that between Kampoong and Colonial Settlements have some discrepancies in spatial configuration. In Kampoong, they have a small 'void space', many streets between houses and the organic patterns. In Colonial settlements, the spatial configuration is planned well with grid pattern. In context influences of Musi River to the settlements, only Bagus Kuning complex that has a closed relationship with rivers because those settlements have a connection between inner 'void space' with riparian 'void space'.
\end{abstract}

Keywords: spatial configuration; 'void space'; space syntax analysis; riparian area

\section{Introduction}

Palembang is known as one of the oldest city in Indonesia and it has a long history. Palembang is also known as a waterfront city because Musi River divides Palembang into two parts: Ilir (North part) and Ulu (South part).

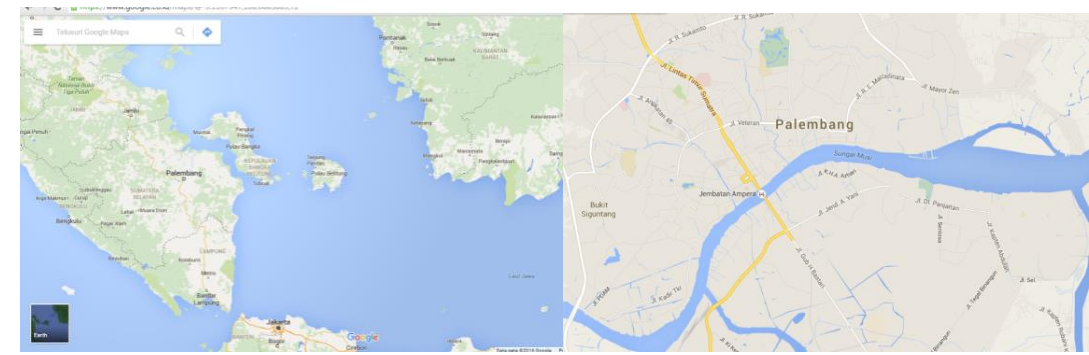

Fig. 1. Palembang Position in South Sumatera (left); Palembang City and Musi River (Right). Source: Google Map 
There are many human settlements beside in riparian ${ }^{1}$ of Musi River, especially human settlements that were built before 1930s. These settlements were established because Musi River became the main transportation route. In this paper, we compare two areas at the vernacular settlements (old Kampoong) and two other areas in Colonial settlements.

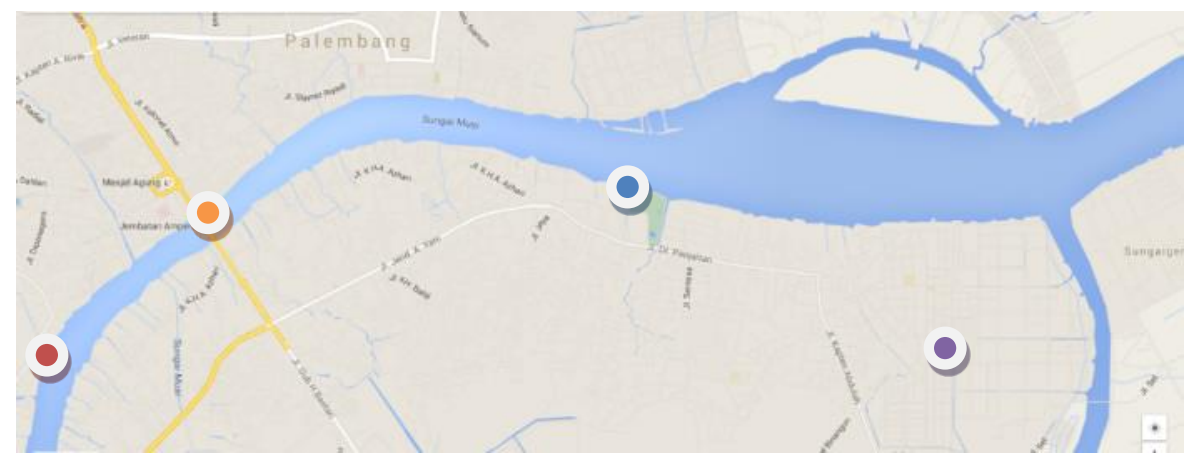

\begin{tabular}{|c|l|}
\hline \multicolumn{2}{|c|}{ Annotation } \\
\hline \multicolumn{2}{|c|}{ Old Kampoong } \\
\hline$\bullet$ & Kampung 3-4 Ulu \\
\hline$\circlearrowright$ & $\begin{array}{l}\text { Kampung Arab 10 } \\
\text { Ulu }\end{array}$ \\
\hline Colonial \\
\hline$\bullet$ & $\begin{array}{l}\text { Komperta Bagus } \\
\text { Kuning }\end{array}$ \\
\hline$\bullet$ & Komperta Plaju \\
\hline
\end{tabular}

Fig. 2. Research area.

The background of this comparative study based on Van de Wal studies in Surabaya. He said that there were the differences between the concepts of open space in Asian and European concepts. Wal said that Asian concepts of open space is a pasive space, which means that an open space as a result of mass formation (space between building) and the European concepts is an active space, because space as a goal of mass formation (Zahnd, 1999). In this paper, we also compare old Kampoong as a representative of Asian concepts and Colonial Settlements as a representative of European concepts of spatial configuration. The research questions are: what are the differences between Kampoong and Colonial Settlements in spatial configuration? Does the Musi River have influence in spatial configuration on that case?

\section{Research Theory, Methods and Case Studies \\ 2.1. Spatial Configuration}

In this paper, spatial configuration is viewed from solid-void spatial configuration. Luz called it as 'solid-void dialectic'. Luz said that in the conventional map or urban plan of a city, the black or full-colour solid rectangles represent buildings and monuments to go or visit, whereas the empty and white lines usually define streets, squares, gaps between buildings and thus voids. However, while the traditional practice of place-making disciplines presupposes that the fixed spaces of staying of cities (buildings, edifices and other urban volumes) are the solid matter and that spaces of going just the hollows in between, this paper suggests an inversion of that condition. This paper focusing in 'void space'. Lee said that void structures can be divided into three categories: void structure in nature, void structure in human settlements, and the movement pattern of people. These undefined formal relationships between the void structures - the void created by the topography, human settlements, movement pattern of people and architectural elements - are the major consideration in defining architectural configuration. By relating these voids, physical and psychological boundaries are eliminated, and the architecture becomes the connector between nature and people.

To be more clear about 'void space' in settlements, use space syntax as a tool of analysis. Zhai and Baran said that space is considered as a discrete system, which follows certain logical rules in form of configurations. Concept of configuration works as an important base of space syntax theory, which is defined as a set of independent relations in which each is determined by its relation to all the others (Zhai \& Baran, 2013). Configurational modeling of urban networks has become a major focus of space syntax studies (Dawson, 2003).

Haeng Woo Shin, Da Eun Kim and Young Ook Kim's research, (Shin, Kim, \& Kim, 2007) compared between traditional village and apartment. They study attempt to suggest a direction for planning modern dwellings through a

${ }^{1}$ Riparian: relating to or living or located on the bank of a natural watercourse (as a river) or sometimes of a lake or a tidewater $\langle$ riparian trees $>$ (source: http://www.merriam-webster.com/dictionary/riparian ) 
comparison of modern dwelling sites and traditional dwelling sites in order to deal with the future changes in spatial configuration. The characteristics of dwelling sites were identified through the process of quantitatively analyzing and comparing the spatial configuration of traditional villages and apartment complexes (Shin et al., 2007). That comparation between traditional and 'modern' dwelling become background knowledge in this paper, and make comparation between Asian and European concepts of settlements.

\subsection{Space Syntax Analysis}

Space syntax theory has two main focuses: 1 . Examination of linear space and the paths of movement along these spaces; and 2. Study of spaces in building and how they contribute to the reproduction of social schemas. Movement and prolonged occupation are fundamental poles of our experience of space (Zhai \& Baran, 2013). In this paper, we can compare people's movement in Kampoong and Colonial settlements. This comparative study using convex analysis, axial map analysis and visibility graph analysis for technic analysis. These three steps of technic analysis have purpose to understand the characteristic of 'void space' in each settlements. In Zhai and Baran's research, the purpose of convex map analysis is to define clear boundaries of spaces and their relations; second, the purpose of an axial map technic is to understand the degree of visual connections, which is not like buildings in urban area that may conflict with actual spatial accessibility; third step is visibility graph analysis that have a purpose to identify objects that could block line of sight (Zhai \& Baran, 2013). If Zhai and Baran used space syntax analysis to view urban park, then this paper views 'void space' at human settlements. Software analysis of this paper is using depthmapX (https://varoudis.github.io/depthmapX/).

\subsection{Case Studies}

\subsubsection{Old Kampoong}

This research using two old Kampoongs as case studies. These Kampoongs are located in riparian of Musi River. One Kampoong is called as Kampung 3-4 Ulu because located in kelurahan 3-4 Ulu.
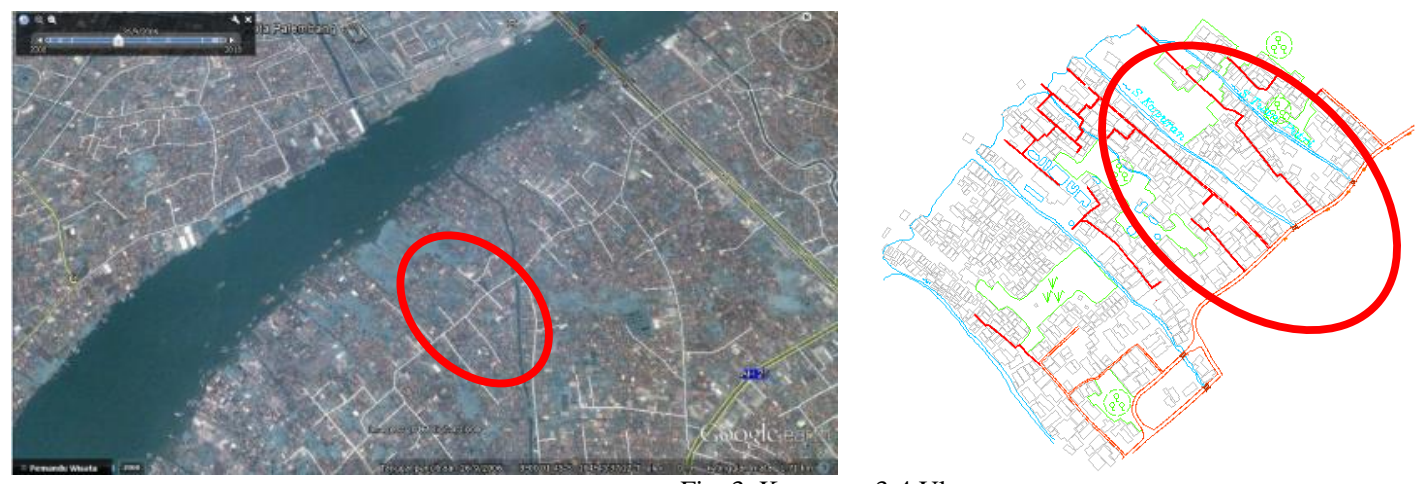

Fig. 3. Kampung 3-4 Ulu.

(Left: 3-4 Ulu and Surroundings, source: google earth pro); (Right: Detail area of Kampung 3-4 Ulu, source: Bappeda Palembang, 2006)

Another old Kampoong is called as Kampung Arab 10 Ulu because most citizens of 10 Ulu are descendants of Arab (Yaman). This Kampoong is unique because located not far from Klenteng Candranadi, one of the oldest klenteng in Palembang and in the Chinese settlements. 

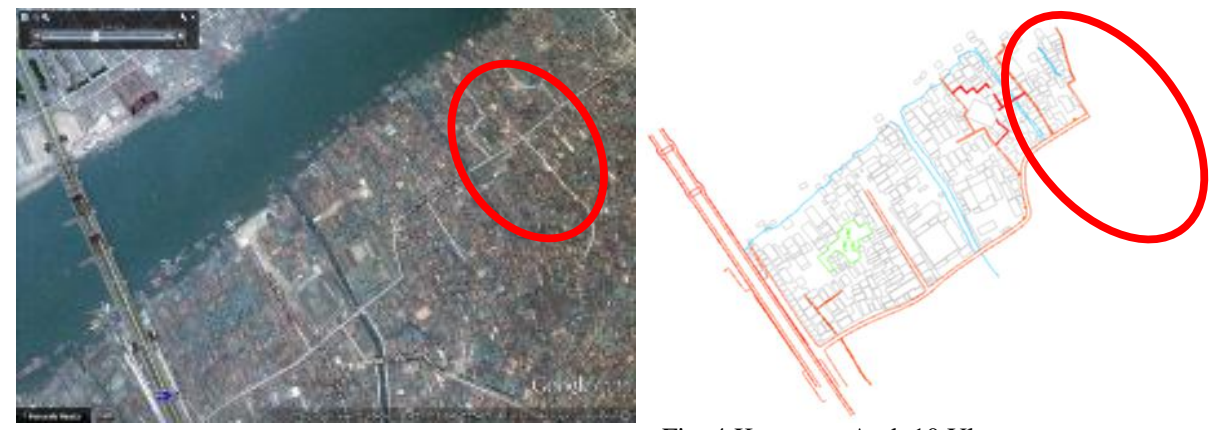

Fig. 4 Kampung Arab 10 Ulu.

(Left: 10 Ulu and Surroundings, source: google earth pro); (Right: Detail area of Kampung 10 Ulu, source: Bappeda Palembang, 2006)

\subsubsection{Colonial Settlements}

In this research, Colonial settlements are cluster areas of Pertamina. The first cluster is called as Komperta (kompleks perumahan) Plaju. This cluster was built by Shell company in 1830 (source: http://www.palembangtourism.com/destinasi-346-kompleks-pertamina-kota-palembang.html).
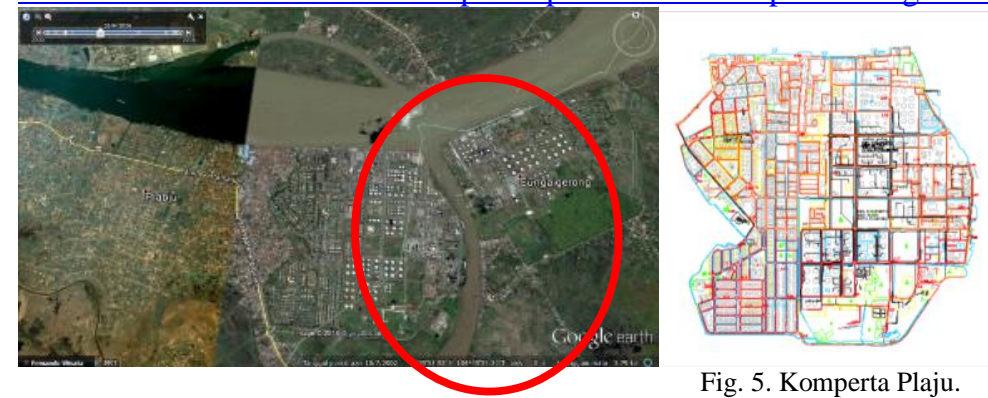

Fig. 5. Komperta Plaju.

(Left: Komperta Plaju and Surroundings, source: google earth pro); (Right: Detail area of Komperta Plaju, source: Bappeda Palembang, 2006)

The other cluster is called as Komperta Bagus Kuning. The differences between Komperta Plaju and Komperta Bagus Kuning are that Komperta Bagus Kuning has residential only while Komperta Plaju beside residential, it also has oil refinery.
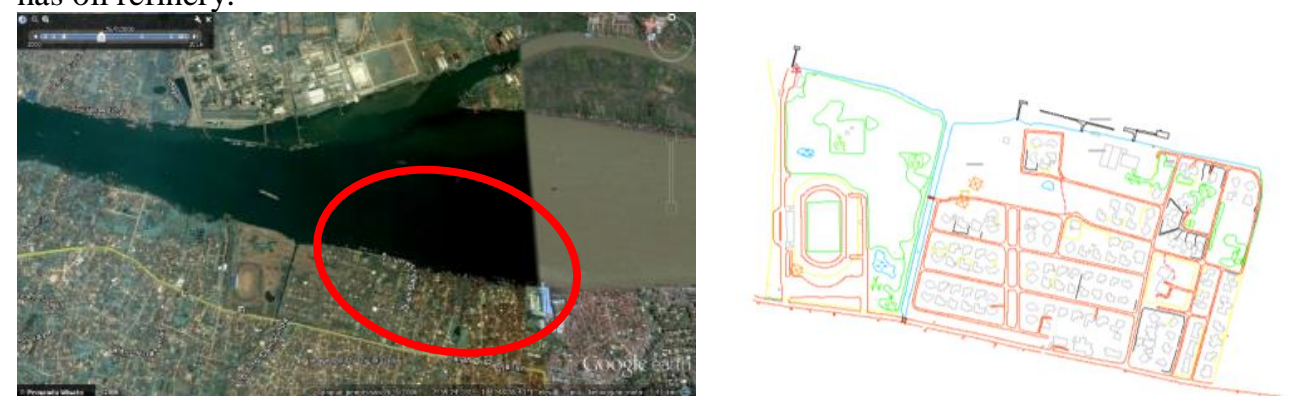

Fig. 6. Komperta Bagus Kuning.

(Left: Komperta Bagus Kuning and Surroundings, source: google earth pro); (Right: Detail area of Komperta Bagus Kuning, source: Bappeda Palembang, 2006)

\section{Results and Discussion}

\subsection{Aplication of Convex Map Analysis}

Convex maps were first introduced by Hillier and Hanson in The Social Logic of Space (Hillier, 1996), and have since become a standard diagram of space syntax, particularly in the analysis of interior of buildings (Miranda Carranza, 2013). 
In space syntax, when converting the continuous space into a connected set of discrete units, it uses the concept of convex space partitioning or simply axial mapping. The procedure to generate the convex map involves taking a given spatial structure and partitioning it into a set of "fewest and fattest" convex spaces. The procedure for generating the convex maps is iterative, starting with the identification of the fattest of the convex spaces and then progressively identifying the next largest one until the entire area is subdivided into a set of convex spaces (Kim, Jun, Cho, \& Kim, 2008). As with VGA, convex spaces that are one step away from the root space are at depth 1, those two steps was at depth 2 and so on. Shallow space will be coloured red through to dark blue (deep spaces) (Pinelo \& Turner, 2010).

In Zhai's research talks about convex map, the challenge is to define clear boundaries of individual park spaces and their relations (Zhai \& Baran, 2013). In this paper, convex map is used to identify 'void spaces' and their relations at two different settlements.

Table 1. Convex Map Analysis

\begin{tabular}{|c|c|c|}
\hline Old Kampoong & Connectivity & Integration $[\mathrm{HH}]$ \\
\hline \multicolumn{3}{|l|}{ 3-4 Ulu } \\
\hline \multicolumn{3}{|l|}{10 Ulu } \\
\hline Colonial Settelements & Connectivity & Integration \\
\hline Komperta Plaju & & \\
\hline
\end{tabular}



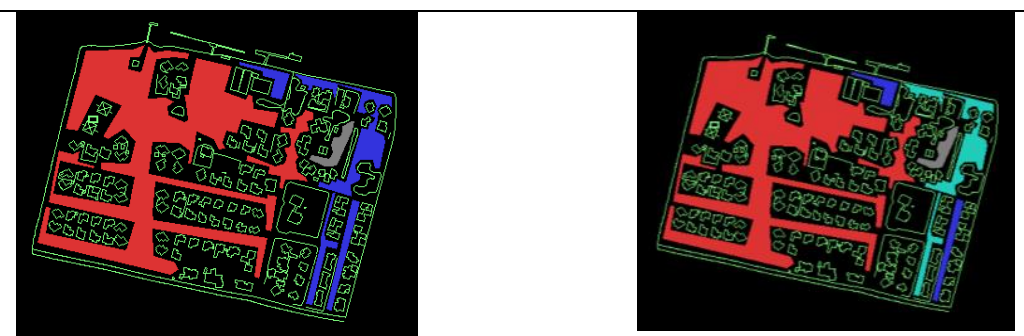

The result of convex map analysis shows (see Table 1):

- Old Kampoongs have a few 'void space' and not too 'fat'. All 'void space' mostly are 'deep spaces'.

- Colonial Settlements have more 'void space' than old Kampoong. That 'void space' also fatter than in old Kampoongs, also that space is 'shallow space'.

Based on those results we can go back to Van de Wal's studies which compare between Asian and European concepts of mass formation (Zahnd, 1999). The fewest and 'deep spaces' at Kampoong can be formed because the consequences of mass formation. The emergence of 'void space' as a result of the establishment of people's houses. The contradiction with Colonial settlements at that area is that the 'void space' was planned as 'green area'. Patterns at Colonial settlements using grid patterns while at Kampoong using organic patterns.

Futhermore, those results above are checked by using axial map analysis. Axial map analysis can analizing the connection between two spaces which is connected by streets.

\subsection{Aplication of Axial Map Analysis}

In Zhai and Baran's research, an axial map technic has purpose to understand degree of visual connections, which is not like buildings in urban area that may conflict with actual spatial accessibility (Zhai \& Baran, 2013). In this paper, axial map analysis has purpose to understand the connections between 'void space' and it connections with rivers. Such models are constructed by breaking up the urban layout of a city or town into the fewest and longest lines of sight and access that pass through all possible routes of movement. (Dawson, 2003).

Table 2. Comparative Axial Map Analysis

\begin{tabular}{cccc}
\hline Old Kampoong & Connectivity & Integration [HH] \\
3-4 Ulu & &
\end{tabular}




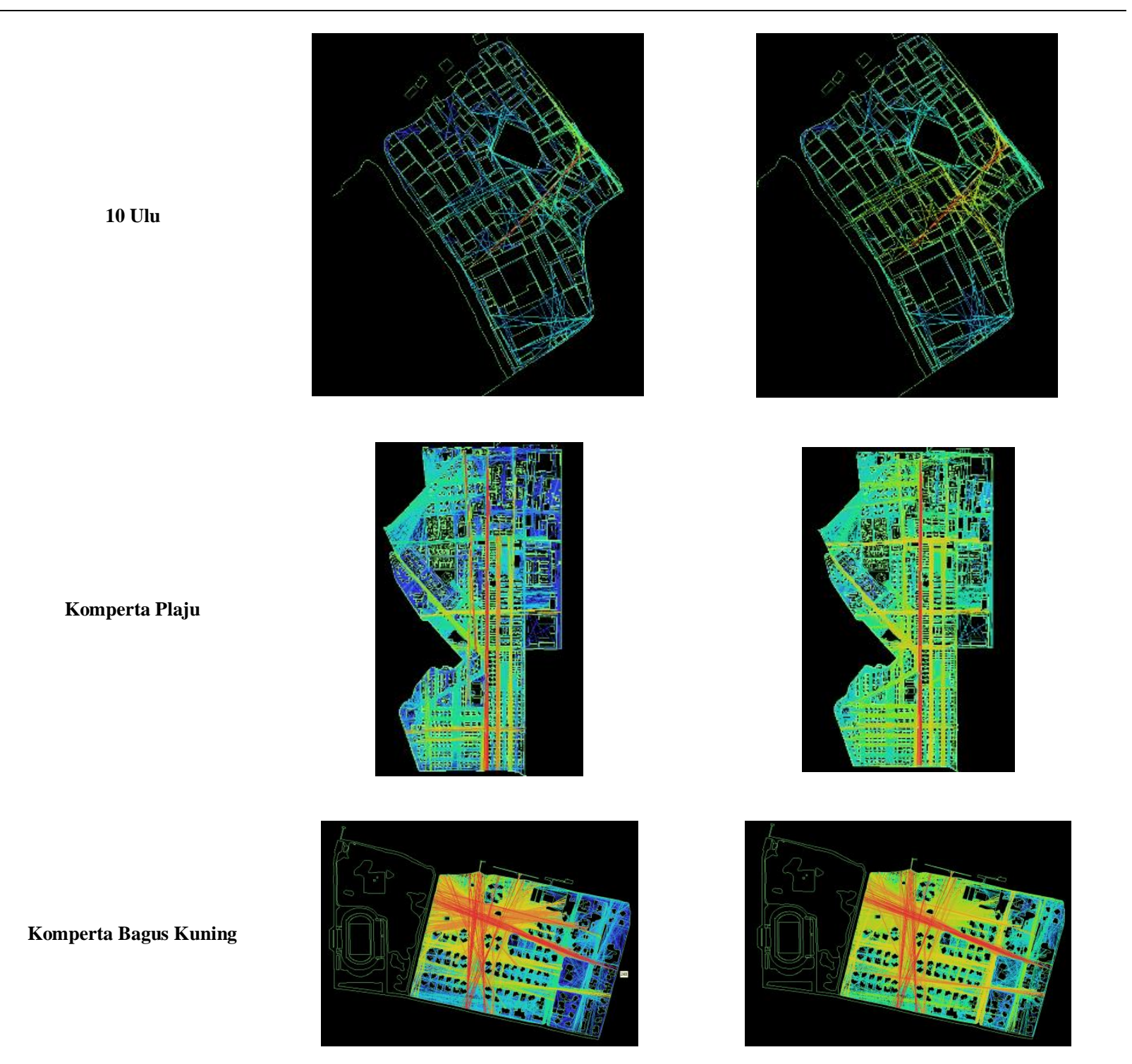

\section{Based on}

Table 2 shows, that Kampoong streets become an active space. In Colonial settlements, the grid spatial systems make the settlements with main streets which have strong connectivity between space in the settlements (deep red colour). Based on the same table, we can see that at Kampoong, the connectivity between 'void space' focusing in narrow street (showed by light green-yellow colour). Contrast at colonial settlements, the connectivity between space is very strong and at Komperta Plaju with main streets (based on intregration side with straight deep red colour line). Komperta Bagus Kuning did not have main streets, but it has connectivity and integration between inner 'void space' and riparian area. 


\begin{tabular}{clccc}
\hline Old Kampoong & & Minimum & Maximum & Avarage \\
\hline \multirow{3}{*}{ 3-4 Ulu } & Connectivity & 2 & 52 & 14,7575 \\
& Integration & 0,984 & 2,213 & 1,474 \\
& Mean Depth & 3,869 & 7,605 & 5,629 \\
& Node Count & 536 & 536 & 536 \\
& & & 91 & 22,919 \\
\multirow{2}{*}{$\mathbf{1 0}$ ulu } & Connectivity & 2 & 4,751 & 2,351 \\
& Integration & 1,327 & 5,725 & 3,352 \\
& Mean Depth & 2,304 & 457 & 457 \\
Kode Count & 457 & 2190 & 350,003 \\
& Connectivity & 1 & 9,997 & 4,476 \\
Komperta Plaju & Integration & 3,941 & 5,820 & 2,829 \\
& Mean Depth & 3 & 14241 & 14241 \\
& Node Count & 14241 & 1907 & 590,802 \\
& Connectivity & 6 & 9,995 & 6,512 \\
& Integration & 1,012 & 3,687 & 2,129 \\
& Mean Depth & 1,739 & 5810 & 5810 \\
\hline
\end{tabular}

The resulting axial map also can then be analyzed using a number of statistical measures that describes the configurational properties of the network. A measure of how accessible each axial line segment is to neighboring lines can be obtained by simply counting the number of connections per segment (Dawson, 2003). This analysis to completed line analysis on Table 2.

\section{Based on}

Based on

Table 2 shows, that Kampoong streets become an active space. In Colonial settlements, the grid spatial systems make the settlements with main streets which have strong connectivity between space in the settlements (deep red colour). Based on the same table, we can see that at Kampoong, the connectivity between 'void space' focusing in narrow street (showed by light green-yellow colour). Contrast at colonial settlements, the connectivity between space is very strong and at Komperta Plaju with main streets (based on intregration side with straight deep red colour line). Komperta Bagus Kuning did not have main streets, but it has connectivity and integration between inner 'void space' and riparian area.

Table 3, we can see that the old Kampoongs have a fewer axial line (10 Ulu has 457 axial lines, 3-4 Ulu has 536 axial lines) than Colonial settlements (Komperta Bagus Kuning has 5810 axial lines; Komperta Plaju has 14241 axial lines). These numbers of axial lines show how accessible between space in those settlements. Table 3 showed, that space at Colonial settlements is more accessible than at Kampoong.

\subsection{Aplication of Visibility Graph Analysis}

In the third step of analysis using visibility graph analysis. Zhan and Baran using visibility graph analysis to identify objects that could block line of sight (Zhai \& Baran, 2013). In this paper, this analysis is used to identify visibility connection between 'void space' at settlements, especially visibility conectivity at riparian area.

In Table 4, we can see that old Kampoong has narrow 'void spaces' which can be identified by eye. At 3-4 Ulu, that 'void space' is located on riparian area while at $10 \mathrm{Ulu}$, it is located in 'land' side. Contradiction with old Kampoong, Colonial settlements have a large area of 'void space', but only Komperta Bagus Kuning that has visibility connection 'void space' with Musi River and that is a large area.

\begin{tabular}{llc}
\multirow{2}{*}{ Old Kampoong } & $3-4$ Ulu & 10 Ulu \\
\cline { 2 - 3 }
\end{tabular}



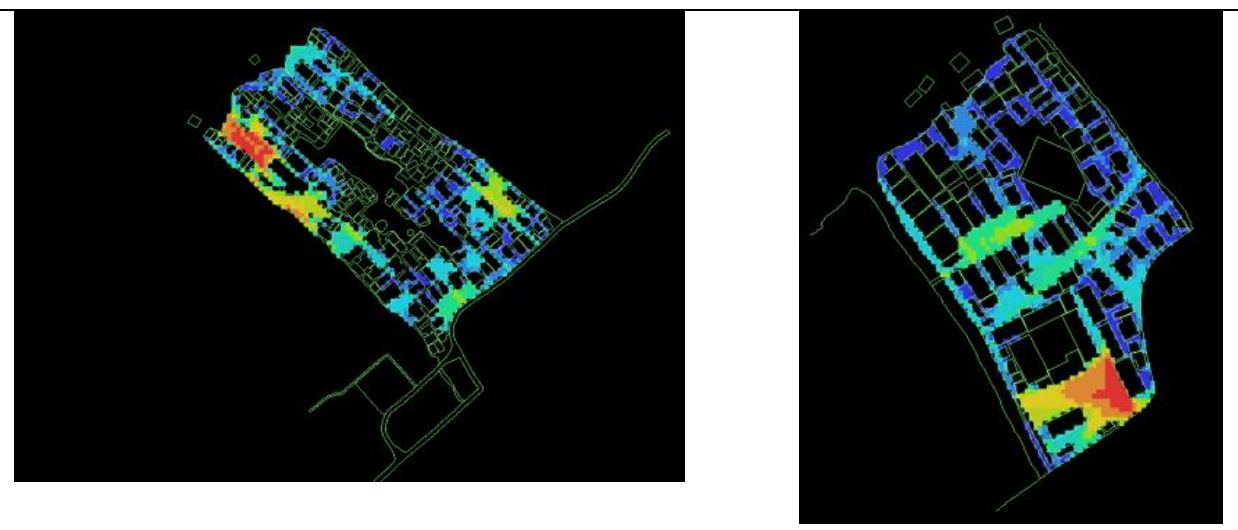


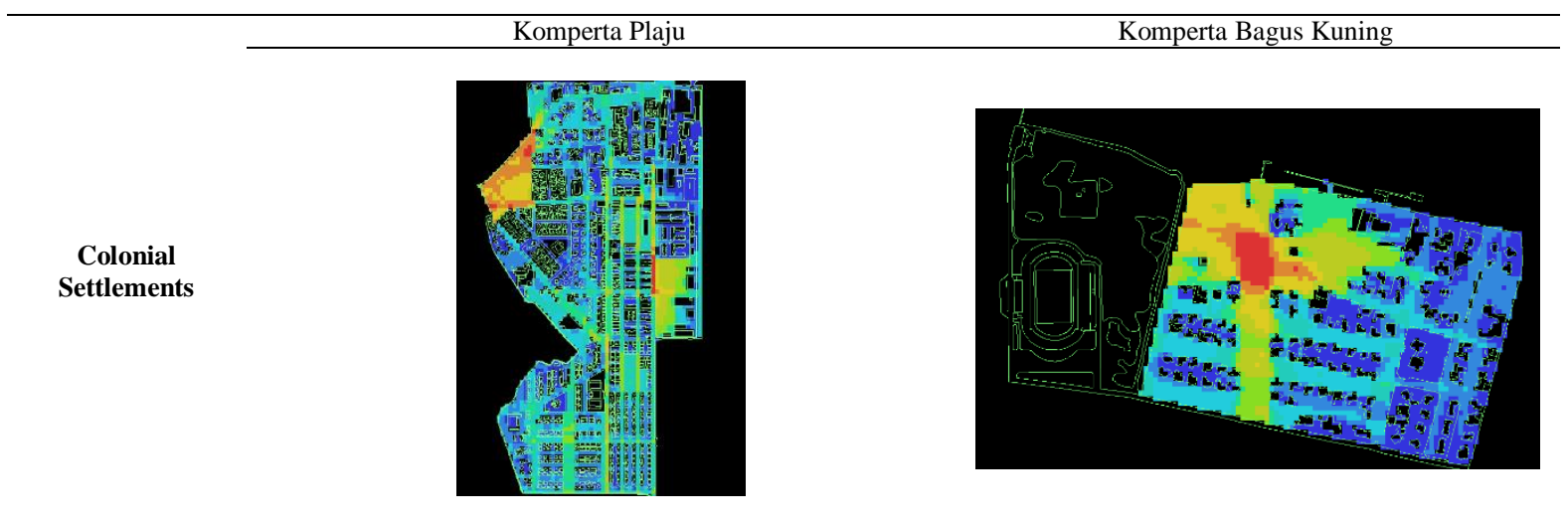

With these three steps we can have temporary conclusion that old Kampoong has tighter 'void space' than Colonial settlements. 'Void space' at old Kampoong appears as consequences of the construction houses. That is why, in the second step of analysis (axial map analysis) we can see that 'void space' at Kampoong is dominated by narrow streets. With visibility analysis we can see that at old Kampoong, there are only a few 'void space' can be identified (from yellow to red colour) and many 'void space' cannot be identified (from green to dark blue). That unidentified 'void space' is dominated by narrow street (space between houses). In Komperta Plaju, there are few unidentified 'void space'. This area is dominated by a visibility 'void space' (light green to red colour). If we see on Table 2, Komperta Plaju has a grid patterns and wide streets that connected 'void space' with the front of the house or park.

Different from Komperta Plaju and also old Kampoong, Komperta Bagus Kuning has a special result. This area have a strong connectivity with Musi River, which is different from Kampoong 3-4 Ulu that at Komperta Bagus Kuning, the inner and riparian 'void space' have visibility and axial connectivity and also in large area.

\subsection{Discussion}

The result above said that only Komperta Bagus Kuning that has strong visibility and connectivity with Musi River. Questions arise from the result: Does only Komperta Bagus Kuning that have that situation? How to view the spatial configuration which has a connection with Musi River? This paper addresses other area in Palembang to compare with Komperta Bagus Kuning. This location is called as Kampung Kapitan at 7 Ulu. Kampung Kapitan is allegedly built in mid 19th century.

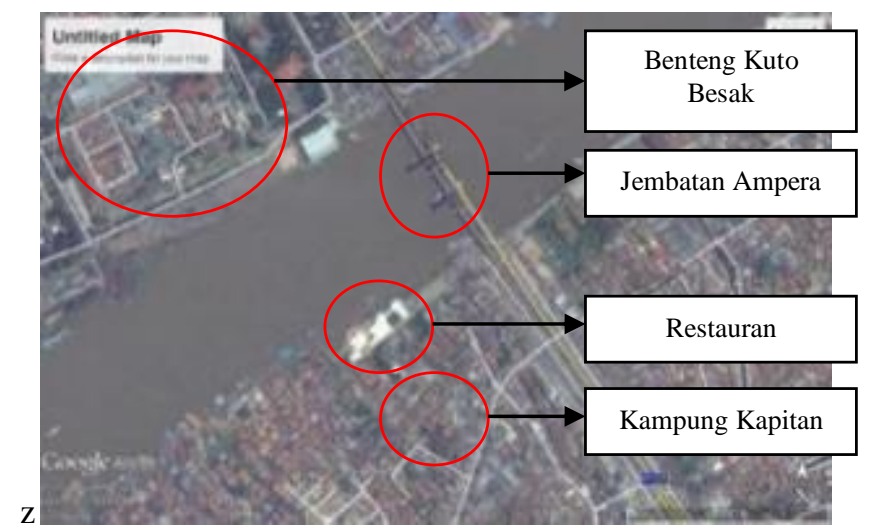

Fig. 7. Location of Kampung Kapitan.

Based on Fig. 8, we can see that 'void space' at Kampung Kapitan have a strong connection with Musi River. This was happened because Kampung Kapitan has a large 'void space' in river bank. That space has connection in 
'void space' in front of Kapitan or Mayor House. In the axial map analysis (right side in Fig. 8), we can see the street which has direct and strong connection between inner 'void space' and outer 'void space' (riparian area). In visibility graph analysis also showed that 'void space' can be clear identified.

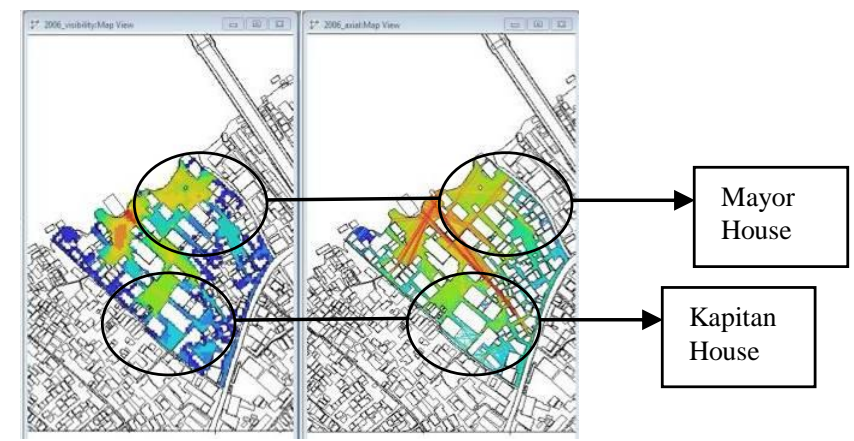

Fig. 8. Visual graph analysis (left) and axial map analysis (right) of Kampung Kapitan.

Kampung Kapitan's case showed that 'void space' in riparian area must have a connection with inner 'void space'. According to Figure 8, that in old Kampoong and Colonial settlements showed that they have inner 'void space', and only Komperta Bagus Kuning that has connectivity between inner and riparian area of 'void space'.

\section{Conclusions}

In this paper shows that old Kampoongs which as a representative of Asian concepts of spatial configuration, have an organic patterns. The 'void space' was configured by houses constructions. 'Void space' was dominated by narrow streets.

In the Colonial settlements which as a representative of European concepts of spatial configuration, have a grid patterns. The 'void space' was already planned as 'green area' of settlements. Connectivity at Komperta Plaju arises in main streets as consequences of grid patterns. Visibility and connectivity at Komperta Bagus Kuning was focused at riparian area, which is a large green area.

In context of connectivity with Musi River, only Komperta Bagus Kuning that has a little difference because it has a strong connectivity and visibility with Musi River. This can be happened because of special spatial configuration. In the same situation happened at Kampung $7 \mathrm{Ulu}$, the spatial configuration which has connectivity and visibility between inner 'void space' and outer 'void space' at riparian area, makes both area (Komperta Bagus Kuning and Kampoong 7 Ulu) have connection with Musi Rivers.

\section{References}

Dawson, P. C. (2003). Analysing the effects of spatial configuration on human movement and social interaction in Canadian Arctic communities. In J. Hanson (Ed.), Proceedings . 4th International Space Syntax Symposium London (p. 37.1-37.14). London: Bartlett School of Graduate Studies, University College London.

Hillier, B. (1996). Space is the machine: a configurational theory of architecture. New York: Cambridge University Press.

Kim, H., Jun, C., Cho, Y., \& Kim, G. (2008). INDOOR SPATIAL ANALYSIS USING SPACE SYNTAX. In The International Archives of the Photogrammetry, Remote Sensing and Spatial Information Sciences. Vol. XXXVII. Part B2. Beijing.

Miranda Carranza, P. (2013). Convex maps, some basic concepts and a new method to generate them. In Architectural Morphology: Investigative modelling and spatial analysis (pp. 1-6). Stockholm: KTH Royal Institute of Technology.

Pinelo, J., \& Turner, A. (2010). Introduction to UCL Depthmap 10. London.

Shin, H. W., Kim, D. E., \& Kim, Y. O. (2007). A COMPARATIVE STUDY ON THE SPATIAL CONFIGURATION OF TRADITIONAL VILLAGES AND APARTMENT COMPLEXES IN KOREA Haeng Woo Shin. In Proceedings, 6th International Space Syntax Symposium. Istanbul.

Zahnd, M. (1999). Perancangan kota secara terpadu : teori perancangan kota dan penerapannya. Yogyakarta: Kanisius.

Zhai, Y., \& Baran, P. (2013). APPLICATION OF SPACE SYNTAX THEORY IN STUDY OF URBAN PARKS AND WALKING. In Proceedings of the Ninth International Space Syntax Symposium. Seoul. 



\section{$8^{\text {th }}$ International Conference on Architecture Research and Design (AR+DC)}

November 1-2, 2016 